\title{
FEATURES OF MANAGING THE DEVELOPMENT OF INTERETHNIC RELATIONS IN RUSSIA BASED ON ECONOMIC AND GEOGRAPHICAL POSITION (ON THE EXAMPLE OF THE REGIONS OF THE VOLGA FEDERAL DISTRICT)
}

\section{MINNAHMATOVICH-BIKTIMIROV Niyaz ${ }^{1}$, ANATOLEVICH-RUBTZOV Vladimir ${ }^{2}$, VIKTOROVICH-ROZHKO Mikhail ${ }^{3}$, RAFAELEVICH-MUSTAFIN Marat ${ }^{4}$, ALEKSANDROVNA-SHABALINA Svetlana ${ }^{5}$}

\author{
${ }^{I}$ Kazan Federal University, Institute of Management, Economics and Finance (RUSSIA) \\ ${ }^{2}$ Kazan Federal University, Institute of Management, Economics and Finance (RUSSIA \\ ${ }^{3}$ Kazan Federal University, Institute of Management, Economics and Finance (RUSSIA) \\ ${ }^{4}$ Kazan Federal University, Institute of Management, Economics and Finance (RUSSIA) \\ ${ }^{5}$ Kazan Federal University, Institute of Management, Economics and Finance (RUSSIA) \\ E-mails: Niyaz825@mail.ru; vrubtzov.57@mail.ru;romikhail@yandex.ru; sdk-bink.mmr@mail.ru; \\ sshabalina74@gmail.com
}

\begin{abstract}
The article shows the relevance of ethnic research in the modern world. The paper summarizes the scientific literature, published by specialists of different sciences concerned with ethnicity and ethnic processes in Russia and other countries. The Volga Federal District, which is one of the most multi-ethnic territories of Russia, was chosen as an object of study. The ethnic composition and interethnic relations in the regions of the Volga Federal District are analyzed. The forecast associated with the ethnic characteristics of the settlement within the district is presented. The influence of the economic and geographical position of the district on the dynamics of the ethnic composition of its population is shown. Conclusions based on current trends in the development of ethnic processes and inter-ethnic relations in the regions of the Volga Federal District.
\end{abstract}

Keywords: ethnic group, ethnic composition, ethnic selectivity, interethnic marriages regions, Volga Federal District

JEL: J15

DOI: $10.5937 /$ intrev2102047M

UDC: $323.1(=161.1)$

COBISS.SR-ID 43530761 


\section{INTRODUCTION}

The revival period that is characteristic of many nations today is accompanied by increasing in interest and appealing to ethnic values a surge of ethnic identity, with the desire of raising the status of national languages, appealing to the culture, customs, traditions of ancestors, as necessary elements for creating a holistic system. National-cultural societies are an important part of consolidation [3].

People as an entire nationals turn to their roots. This appeal is evident not only in the search form the "mysterious soul of the people", but also due to the resuscitation of old folk customs or rituals, and an attempt folklorisation professional culture. Sometimes this need could rise to the most ambitious goals as an attempt to create and reestablish their national state. There are many examples in the world when such "interests", receiving the corresponding resistance on the part of other nations, cause problems of interethnic tensions [13].

\section{METHODOLOGY}

The methods of analysis and synthesis of scientific literature published in Russian publications and abroad were used in this article. General approaches tested during the research.

The modern methods and decisions in the demographic analysis, as a rule, are an influence of time and new problems of studying the changing demographic reality. At the same time, the demographic analysis, in an escalating measure relies on own methodical developments and conceptual constructions.

The methods applied in the demographic analysis are subdivided into the following groups: 1) statistical; 2) graphic and analytical; 3) mathematical; 4) sociological; 5) actually demographic 6) cartographical.

\section{RESULTS}

In the implementation of public policies, Russia is trying to take into account the multi-ethnicity and multi-confessionals of the predominant part of the Russia regions, which contributes to the organization of full-scale studies of interethnic and inter-confessional relations.

The Volga Federal District is a multiethnic territory, where the ethnic factor among the peoples of the Finno-Ugric group of the Uralic language family that originally lived here and among the peoples of the Turkic group of the Altai language family has played a special role for many years.

The main part of the district population, Russians, has always been famous for their breadth of soul, philanthropy, tolerance, hospitality, and hospitality. The main features of the Russian people include the willingness to help, unpretentiousness, high civic solidarity, etc. [5].

Among the 14 regions of the Volga Federal District, 12 Russians are leading in terms of population. As for national republics, only in Tatarstan, they are inferior in numbers to the Tatars and in the republic of Chuvashia to the Chuvash.

The national composition of the Volga Federal District is as follows: $66.3 \%$ - Russians, $13.4 \%$ - Tatars, 4.3\% - Bashkirs, $4.3 \%$ - Chuvashs, 2.0\% - Mordovians, $1.7 \%$ - Udmurts, 1, 6\% are Mari, as well as representatives of other nations, nationalities and ethnic groups (https://psyjournals.ru). Only in the Republic of Tatarstan live 173 nationalities. In total, 179 national-cultural autonomies were registered in the Volga Federal District.

The dynamics of ethnic composition in the regions of the Volga Federal District shows that individual ethnic groups are better developed in their national-territorial entities than outside it [16].

Territorial differences in fertility in the Volga Federal District are caused by ethnic characteristics of demographic development, especially this could be observed throughout the 20th century. Nowadays, the ethnic differences in the demographic situation are becoming less [7] [9].

For many parts of the world, it is true that the changes in the migration of the population caused by economic growth, which is typical for all types of countries and manifested both in the purely economic spheres, for example, the labor market, and social - the assimilation of immigrants, interethnic interaction, 
changes fertility. A large number of publications on migration issues have been devoted to these and other consequences [8] [2] [1].

Volga Federal District has an advantageous economic and geographical position in relation to the transit location at the crossroads of future international transport corridors "North-South" and "East-West". According to the capabilities of these highways linking Siberia and Far East, East Asia and, Russia with the European countries of the European continent, this strengthens contacts between representatives of different ethnic and religious groups.

According to N. N. Loginova's research, ethnic groups attach different importance to ethnic differences. For example, the Mordovians ethnic selectivity is low, in Russian, it is more common, and the Tatars is expressed most clearly [16]. According to the scientist the main cause of regional ethnic conflict could lead to the most extreme forms is the politicization of ethnicity [16].

After the 90s of the XX century, interethnic marriages began to play a significant role in the development of the population of the Volga Federal District. To increase the number of interethnic marriages, close friendly interethnic relations, a relatively high migration mobility, especially the population distribution, weakening of traditions and softening of socio-cultural development, a relative coincidence of worldview, etc. are needed [6].

The closeness of the language and culture, compensation imbalance sex ratio also contributes to the growth of marriages performed between different nationalities.

Researches show that women are more careful about the possibility of such marriages than men.

It has long been observed that men and women of different nationalities unequally often enter into international marriages. According to statistics, people who are more likely to enter into inter-ethnic marriages are older than younger ones, and the following relationship can be traced: the higher the level of education and culture of a person, the more tolerant he is of inter-ethnic marriages [15].

Earlier in such marriages, the participation of Russian women was significantly higher than that of Russian men. Due to many factors, the proportion of non-Russian men married to Russian women was higher than the share of non-Russian women married to Russian men. However, due to some features of our country, children born in these families were usually registered as Russians [10].

Within the Republic of Tatarstan, the probability of participation in interethnic marriages is high between Russians and Tatars and quite often occurs between Tatars and Maris, Tatars and Udmurts, Russians and Mordovians, Chuvashs and Mordovians, Maris and Udmurts. In recent years, marriages with Armenians and Azerbaijanis, as well as with other peoples of the Caucasus, have grown [14].

The nature of interethnic marriages in different territories may differ from each other. To some extent, this can be shown by the example of conservation Tatar and Bashkir nation, historically living in adjacent territories. In these nations, Interethnic marriages were extremely rare, especially in rural areas [15].

The vast majority of informants, who were the Germans of the Volga diaspora, find much in common with the Russians in culture. As the research results of Smolnikova N.V. show, the Germans majority of the Volga diaspora form nationally-mixed marriages, the bulk of which form couples between Germans and Russians [12].

The example that the Republic of Tatarstan demonstrates in the field of achieving peace and harmony in inter-confessional relations arouses interest and admiration far beyond the borders of Russia. When the Republic is forced to experience and adapt to the constant quantitative and territorial shifts in the confessional composition of the population, the region is not only satisfied with the current situation but at the same time makes every effort, by constantly monitoring what is happening, being attentive on the part of regional authorities and maintaining and even further strengthening these relations [4].

After the conducted research, we were convinced that there is a need to develop new religious tours, which are laid not only in large cities but also in small historical cities and cover individual rural localities in the region. We have relevant experience in developing such tours, which took into account possible inter-religious and inter-ethnic contacts and assessed possible difficulties. We believe that the prospects for the development of religious tourism in Tatarstan are related to the development of religious tourism of an excursion and educational orientation. 


\section{SUMMARY}

According to our forecasts, in the majority of Russia regions, with a low proportion of a particular nation, their absolute number is prone to continuous reduction. For example, Tatars settled in different regions of the Russian Federation and living far beyond its borders will gradually "return" to their historical homeland, concentrating and localizing among the regions of the Volga Federal District, primarily in the republics of Tatarstan and Bashkortostan. We already can see the trend of returning migrants exerted earlier in the northern and eastern regions of Russia [12].

\section{DISCUSSION AND CONCLUSION}

In this way, the research confirms the special importance of the ethnic factor in the regions of the Volga Federal District which manifests itself in many forms of interaction, also it is not enough to consider only interethnic relations, it is necessary to consider the ethnic-confessional interaction of the regions' population, moreover, due to the peculiarities of the geographical location, historical ties with many CIS countries for this territory, the importance of ethnic migration must be taken into account, in addition, ethnic groups living in the district shows exemplary behavior in the various forms of inter-ethnic behavior and can serve as a role model for many countries and people of the world.

\section{ACKNOWLEDGEMENTS}

The work is performed according to the Russian Government Program of Competitive Growth of Kazan Federal University.

\section{REFERENCES}

[1] Anderson, B. (2014). Nations, migration and domestic labor: The case of the UK. In Women's Studies International Forum 46, 5-12. Pergamon,

[2] Bunakov, Oleg A., Natalia A. Zaitseva, Anna A. Larionova, Vadim A. Zhukov, Marina A. Morozova, \& Nina V. Dmitrieva. (2018). The use of the «soft power» concept in the modern Russian tourism industry. Espacios 39(22), 9.

[3] Davletshin, K.D. (2020). Vzaimodeistvie natzionalnogo I religioznogo factorov v culture I bytu: na primere narodov Povokzhya I Priuralya, traditzionno ispovedayshih islam.

Avtoref.dis.doct.philosof.nauk. - Moskva, 1998.[Elektronnyi resurs]. Rezhim dostupa https://www.dissercat.com/content/vzaimodeistvie-natsionalnogo-i-religioznogo-faktorov-v-kulturei-bytu-na-primere-narodov-pov (дата обращения 24.04.2020).

[4] Gaisin, R. I., I. T., Gaisin, N. M., Biktimirov, E. I., Vlasova, \& Beketova, S. I. (2015). "Demographic projection of the Tatar nation, living in Russia, with the use of the component method." Asian Social Science 11(11), 30-33.

[5] Gorodetskaya, I.M., Rogov, M.G., \& Blokhin, A.B. (2020). Mezhetnicheskiye otnosheniya russkogo, tatarskogo i bashkirskogo narodov. Problemy cotsial'noy psikhologii lichnosti.[Elektronnyy resurs].Rezhim dostupa-https://psyjournals.ru/sgu socialpsy /issue/30283 full.shtml (data obrashcheniya 23.04.2020).

[6] Kulu, H., \& Washbrook, E. (2014). Residential context, migration and fertility in a modern urban society. Advances in Life Course Research 21, 168-182.

[7] Loginova, N.N. (2017). Dinamika etnicheskogo sostava i mezhetnicheskiye otnosheniya v Respublike Mordoviya. Problemy metodologii i metodiki monitoringa sotsial'no-ekonomicheskogo razvitiya regionov Rossiyskoy Federatsii.Materialy Vserossiyskoy konferentsii s Mezhdunarodnym uchastiyem, posvyashchennoy 15-letiyu GKU RM «NTSSEM», Saransk, - 480 s.

[8] Olivetti, C., \& Petrongolo, B. (2017). The economic consequences of family policies: lessons from a century of legislation in high-income countries. Journal of Economic Perspectives 31(1), 205-30. 
[9] Rubtzov, V. A., Rozhko, M. V., Gabdrakhmanov, N. K., Pratchenko, O. V., \& Trofimov, A. M. (2015). Economic-geographical aspects of competitiveness and positioninng of countries and regions. Mediterranean Journal of Social Sciences 6(3), 741-745.

[10] Rubtzov, V. A., Biktimirov, N. M., \& Gabdrakhmanov, N. K. (2016). Ethnic peculiarities of the development of the birth rate in the republic of Tatarstan. International Business Management 10(23), 5651-5656.

[11] Shabalina, S. A., Rubtzov, V. A., \& Pratchenko, O. V. (2014). Differentiation of the territory of tatarstan republic into zones due to their significance for domestic and national and international tourism. Mediterranean Journal of Social Sciences 5(24), 398.

[12] Smol'nikova, N.V. (2020). Sovremennaya etnopolitichsekaya situatsiya i mezhetnicheskiye otnosheniya v Nizhnem Povolzh'ye (na primere nemetskoy diaspory) Avtoref. dis. kand. ist.nauk. Moskva, 1998.[Elektronnyy resurs]. Rezhimdostupa-http://cheloveknauka.com/sovremennaya etnopoliticheskaya-situatsiya-i-mezhetnicheskie-otnosheniya-v-nizhnem-povolzhie]. (data obrashcheniya 23.04.2020).

[13] Stefanenko, T.G. (2009). Etnopsikhologiya: Uchebnik dlya vuzov. 4-ye izd., ispr. i dop. - M.: Aspekt Press, $-368 \mathrm{~s}$.

[14] Stolyarova, G.R. (1993). Russkiye: etnodemograficheskiye protsessy. Tatarstan, 2, rr.S.21.

[15] Titova, T.A. (1995). Etnicheskoye samosoznaniye v natsional'no-smeshannykh sem'yakh (po materialam russko-tatarskikh semey g.Kazani). Avtoref. dis. ...kand. ist. nauk. - Ufa: Fort Dialog, $-16 \mathrm{~s}$.

[16] Vserossiyskaya perepis' naseleniya (2010) goda. Ofitsial'nyye itogi s rasshirennymi perechnyami po natsional'nomu sostavu naseleniya i po regionam.

\section{Article history:}

Received 18 September 2020

Accepted 23 February 2021 